\title{
PENGARUH QUALITY OF WORK LIFE TERHADAP KEPUASAN KERJA KARYAWAN DI PT. GEMALA KEMPA DAYA
}

\author{
Meri Prasetyawati ${ }^{1}$, Kusnudin $^{2}$ \\ ${ }^{1,2}$ Jurusan Teknik Industri, Fakultas Teknik Universitas Muhammadiyah Jakarta \\ Jl. Cempaka Putih Tengah 27 Jakarta Pusat \\ *Email : merie_jeng@yahoo.co.id
}

Diterima: 30 Agustus 2015

Direvisi: 24 September 2015

Disetujui: 12 Nopember 2015

\begin{abstract}
ABSTRAK
Penelitian ini bertujuan untuk mengetahui seberapa besar pengaruh Quality of work life terhadap kepuasan kerja karyawan. Populasi dalam penelitian ini adalah karyawan tetap untuk golongan 3 dan 4 di area Head Office PT. Gemala Kempa daya sebanyak 74 orang, dengan standard error $10 \%$ maka didapatkan sample sebesar 43 responden dengan menggunakan teknik random sampling, skala pengukuran menggunakan likert. Jenis data yang digunakan terdiri dari data primer dan data sekunder, Metode yang digunakan adalah metode deskriptif dan analisa data mengunakan Regresi Linear Berganda. Berdasarkan hasil penelitian dapat disampaikan bahwa untuk variable partisipasi karyawan memiliki tingkat signifikansi 0.014, variabel pengembangan karier memiliki tingkat signifikansi 0.000, variabel komunikasi memiliki tingkat signifikansi 0.000, dan variabel kompensasi memiliki tingkat signifikansi 0.004 yang lebih kecil dari 0.05, maka dapat di simpulkan bahwa variabel variabel tersebut memiliki pengaruh signifikan terhadap kepuasan kerja. Adapun rata - rata Achivement KPI 2013 untuk departement yang berada di area Head Office adalah sebesar $78 \%$ yang berada pada rentang cukup, kemudian setelah dilakukanya penelitian terkait kepuasan kerja , rata - rata Achivement KPI 2014 yakni sebesar 99\% yang berada pada rentang baik, Terjadi kenaikan score sebesar $27 \%$.
\end{abstract}

Kata Kunci : Kepuasan karyawan, Regresi Linear Berganda dan Key Performance Indicator.

\begin{abstract}
This study aims to determine how much influence the Quality of work life on employee job satisfaction. The population in this research is employees of group 3 and 4 in the area Head Office PT. Gemala Kempa Daya as much as 74 people, with a standard error of $10 \%$ are obtained sample of 43 respondents using random sampling techniques, using a Likert scale measurement. The type of data used consist of primary data and secondary data, The method used is descriptive method and data analysis using multiple linear regression. Based on the research results can be delivered to a variable that has a significance level of employee participation is 0.014, career development variables have a significance level of 0.000, communication variables have a significance level of 0.000, nd variable compensation has a significance level of 0.004 which is less than 0.05, it can be concluded that these variables have a significant effect on job satisfaction. The average KPI Achievement in 2013 for the department in area of Head Office is $78 \%$ which is in the range enough, then after execution of research related to job satisfaction, average Achievement KPI 2014 is $99 \%$ which is in the good range, An increase in the score is $27 \%$.
\end{abstract}

Keywords: Employee satisfaction, Multiple linear regression and Key Performance Indicator. 


\section{PENDAHULUAN}

Sumber daya merupakan penggerak utama suatu perusahaan. Salah satu masalah pokok dalam manajemen sumber daya manusia adalah bagaimana mencari cara yang terbaik untuk mencapai kepuasan karyawan. Karyawan di PT Gemala Kempa Daya terdiri dari beberapa golongan diantaranya Golongan 1 untuk Operator, Golongan 2 untuk Team leader, Golongan 3 untuk Foreman, Golongan 4 untuk Section head, Golongan 5 untuk Departement \& Division Head. Adapun yang melatarbelakangi penulis untuk meneliti penelitian ini adalah tingkat turn over karyawan tetap untuk golongan 3 dan 4 ( foreman dan section head) di PT. Gemala Kempa Daya yang cukup tinggi dari periode tahun 2010 - 2013. Data ini pun didukung oleh data hasil exit interview, dimana pada data tersebut menjelaskan beberapa alasan karyawan yang resign dari perusahaan bahwa alasan terbesar karyawan untuk resign dari perusahaan adalah karena mereka mendapatkan kesempatan bekerja yang lebih baik, tentunya hal ini didasari karena adanya ketidakpuasan karyawan dalam bekerja di perusahaan. Oleh karena itu dengan adanya ketidakpuasan dalam bekerja tentunya hal ini dapat mempengaruhi menurunya kinerja karyawan dalam bekerja. Dengan adanya permasalahan ketidakpuasan dalam bekerja yang dihadapi para karyawan gologan 3 dan 4, maka pihak management perlu mengkaji ulang terkait permasalahan tersebut, karena apabilla hal ini tidak secepatnya di tanggulangi tentunya hal ini akan berdampak pada kestabilitas perusahaan dengan mengeluarkan cost lebih dan tidak tercapainya tujuan perusahaan karena produktivitas karyawan yang menurun. Kualitas kehidupan kerja atau Quality of Work Life ( QWL ) merupakan salah satu bentuk filsafat yang diterapkan manajemen dalam mengelolah organisasi pada umumnya dan sumber daya manusia pada khususnya. Sebagai filsafat, kualitas kehidupan kerja merupakan cara pandang manajemen tentang manusia, pekerja dan organisasi. Unsur - unsur pokok dalam filsafat tersebut ialah kepedulian manajemen tentang dampak pekerjaan ada manusia, efektivitas organisasi serta pentingnya para karyawan dalam pemecahan keputusan terutama yang menyangkut pekerjaan, karier, penghasilan dan nasib mereka dalam pekerjaan. Sedangkan menurut Davis dan Newstrom mengemukakan bahwa kepuasan kerja adalah suatu perasaan yang menyenangkan atau tidak menyenangkan diri pegawai yang berhubungan dengan pekerjaanya maupun dengan kondisi dirinya. Dengan kata lain kepuasan kerja mencerminkan sikap tenaga kerja terhadap pekerjaanya.

\section{METODE}

Pada Penelitian ini mengunakan Metode Analisis Deskriptif untuk mendeskriptifkan variabel penelitian tanpa menarik generalisasi. Pengukuran yang dilakukan dengan memberikan angka, baik dalam jumlah responden maupun dalam angka presentase (\%). Analisis Jalur digunakan untuk menguji hipotesis penelitian yang diajukan. Variabel variabel yang digunakan dalam penelitian ini terdiri dari variabel independent (bebas) dan variabel dependent (terikat). Kepuasan karyawan di tetapkan sebagai variabel dependent sedangkan variabel independent adalah faktor - faktor QWL yang terdiri dari Partisipasi karyawan, pengembangan karir, dan komunikasi. Populasi dalam penelitian ini dengan jumlah keseluruhan dari karyawan golongan 3 up di area Head Office PT. Gemala Kempa Daya yang akan menjadi responden berjumlah 74 orang dan peneliti akan mengambil sampel sebanyak 43 orang. Dimana penentuan sampel ini berdasarkan rumus dari Slovin. Teknik analisa data yang digunakan adalah teknik analisa Regresi Linear Berganda. Data yang didapat dari kuisioner setelah di uji validitas dan reabilitas, maka tahap selanjutnya dianalisa dengan menggunakan Regresi Linear Berganda. 
Meri Prasetyawati, Kusnudin : Pengaruh Quality Of Work Life Terhadap Kepuasan Kerja Karyawan Di PT. Gemala Kempa Daya

Jurnal Teknologi. 8 (1) pp 9-15 (C) 2016

\section{HASIL DAN PEMBAHASAN}

Tabel 1. Pengaruh Partisipasi Karyawan $\left(\mathrm{X}_{1}\right)$ terhadap Kepuasan Kerja Karyawan (Y)

\section{Coefficients $^{\mathrm{a}}$}

\begin{tabular}{|c|c|c|c|c|c|}
\hline \multirow[b]{2}{*}{ Model } & \multicolumn{2}{|c|}{$\begin{array}{c}\text { Unstandardized } \\
\text { Coefficients }\end{array}$} & \begin{tabular}{|c} 
Standardize \\
$\mathrm{d}$ \\
Coefficient \\
$\mathrm{s}$ \\
\end{tabular} & \multirow[b]{2}{*}{$\mathrm{t}$} & \multirow[b]{2}{*}{ Sig. } \\
\hline & B & Std. Error & Beta & & \\
\hline (Constant) & 5.806 & 1.218 & & 4.766 & .000 \\
\hline $\begin{array}{l}\text { Partisipasi_Kerja } \\
\text { X1 }\end{array}$ & .201 & .159 & .594 & 6.263 & .014 \\
\hline
\end{tabular}

Dependent Variable: Turn_Over_Y

Berdasarkan tabel 1. coefficient di atas, persamaan analisis regresi linier sederhana yang diperoleh adalah $Y=5,806+0,201$. Sedangkan untuk pengujian hipotesis yang ditunjukkan oleh nilai $t$ bahwa t hitung yang diperoleh adalah sebesar 6,263 dengan nilai signifikansi sebesar 0,014 lebih kecil dari taraf kesalahan 5\% Hal ini berarti bahwa hipotesa yang menyatakan partisipasi karyawan terhadap kepuasan kerja diterima, atau Ho ditolak dan Ha diterima. Pembahasan berkaitan dengan pengaruh partisipasi karyawan terhadap kepuasan kerja dapat dijelaskan bahwa partisipasi kerja yang merupakan faktor Quality of Work Life dalam organisasi dinilai merupakan faktor yang paling signifikan, dimana indikator partisipasi karyawan berupa peningkatan kualitas tim yang dapat memacu tingkat kepuasan kerja karyawan

Tabel 2. Pengaruh Pengembangan Karier $\left(\mathrm{X}_{2}\right)$ terhadap Kepuasan Kerja Karyawan (Y)

Coefficients $^{\mathrm{a}}$

\begin{tabular}{|c|c|c|c|c|c|c|}
\hline \multirow{2}{*}{\multicolumn{2}{|c|}{ Model }} & \multicolumn{2}{|c|}{$\begin{array}{l}\text { Unstandardized } \\
\text { Coefficients }\end{array}$} & \multirow{2}{*}{\begin{tabular}{|c}
$\begin{array}{c}\text { Standardized } \\
\text { Coefficients }\end{array}$ \\
Beta
\end{tabular}} & \multirow[b]{2}{*}{$\mathrm{t}$} & \multirow[b]{2}{*}{ Sig. } \\
\hline & & B & Std. Error & & & \\
\hline \multirow[t]{2}{*}{1} & (Constant) & 1.352 & 1.081 & & 1.251 & .218 \\
\hline & $\begin{array}{l}\text { Pengembangan_Karir } \\
\text { X2 }\end{array}$ & .829 & .149 & .657 & 5.577 & .000 \\
\hline
\end{tabular}

Dependent Variable: Turn_Over_Y

Berdasarkan tabel 2. coefficient di atas, persamaan analisis regresi linier sederhana yang diperoleh adalah $Y=1,352+0,829$. Sedangkan untuk pengujian hipotesis yang ditunjukkan oleh nilai t bahwa t hitung yang diperoleh adalah sebesar 5,577 dengan nilai signifikansi sebesar 0,000 lebih kecil dari taraf kesalahan 5\%, hal tersebut menunjukkan bahwa variabel pengembangan karir memberikan pengaruh positif terhadap kepuasan kerja. Hal ini berarti bahwa hipotesa yang menyatakan pengembangan karir terhadap kepuasan kerja diterima, atau Ho ditolak dan $\mathrm{Ha}$ diterima. Pembahasan berkaitan dengan pengaruh pengembangan karir terhadap kepuasan kerja dapat dijelaskan bahwa pengembangan karier yang merupakan faktor Quality of Work Life dalam organisasi 
dinilai merupakan faktor yang paling signifikan, dimana kesempatan untuk menjadi orang penting di lingkungan perusahaan sudah seyogianya terbuka lebar, begitupun syarat - syarat promosi yang tidak menyulitkan bagi karyawan, sehingga karyawan mendapatkan kepastian karier yang jelas dari perusahaan dan dapat merancang sendiri apa yang mereka inginkan di masa yang akan datang.

Tabel 3. Pengaruh Komunikasi (X3 ) terhadap Kepuasan kerja Karyawan (Y)

\begin{tabular}{|c|c|c|c|c|c|c|}
\hline \multicolumn{7}{|c|}{ Coefficients $^{\mathrm{a}}$} \\
\hline & & \multicolumn{2}{|c|}{$\begin{array}{l}\text { Unstandardized } \\
\text { Coefficients }\end{array}$} & \begin{tabular}{|c} 
Standardize \\
$d$ \\
Coefficients
\end{tabular} & \multirow[b]{2}{*}{$\mathrm{t}$} & \multirow[b]{2}{*}{ Sig. } \\
\hline \multicolumn{2}{|c|}{ Model } & B & Std. Error & Beta & & \\
\hline 1 & (Constant) & 2.414 & 1.081 & & 2.232 & .031 \\
\hline & $\begin{array}{l}\text { Komunikasi_ } \\
\text { X3 }\end{array}$ & .650 & .142 & .583 & 4.590 & .000 \\
\hline
\end{tabular}

Dependent Variable: Turn_Over_Y

Berdasarkan tabel 3. coefficient di atas, persamaan analisis regresi linier sederhana yang diperoleh adalah $Y=2,414+0,650$. Sedangkan untuk pengujian hipotesis yang ditunjukkan oleh nilai $\mathrm{t}$ bahwa $\mathrm{t}$ hitung yang diperoleh adalah sebesar 4,590 dengan nilai signifikansi sebesar 0,000 lebih kecil dari taraf kesalahan 5\%, hal tersebut menunjukkan bahwa variabel komunikasi memberikan pengaruh positif terhadap kepuasan kerja. Hal ini berarti bahwa hipotesa yang menyatakan komunikasi terhadap kepuasan kerja diterima, atau Ho ditolak dan Ha diterima. Pembahasan berkaitan dengan pengaruh komunikasi terhadap kepuasan kerja dapat dijelaskan bahwa dalam variabel komunikasi yang merupakan faktor Quality of Work Life dalam organisasi dinilai faktor yang paling signifikan, dimana sikap selalu berfikir positif dan teman kerja serta atasan yang kooperatif merupakan hal-hal yang memacu kinerja karyawan, sehingga pekerja akan merasa nyaman dan kondisi yang harmonis dalam bekerja.

Tabel 4. Pengaruh Kompensasi (X4) terhadap Kepuasan kerja karyawan (Y)

\section{Coefficients $^{\mathrm{a}}$}

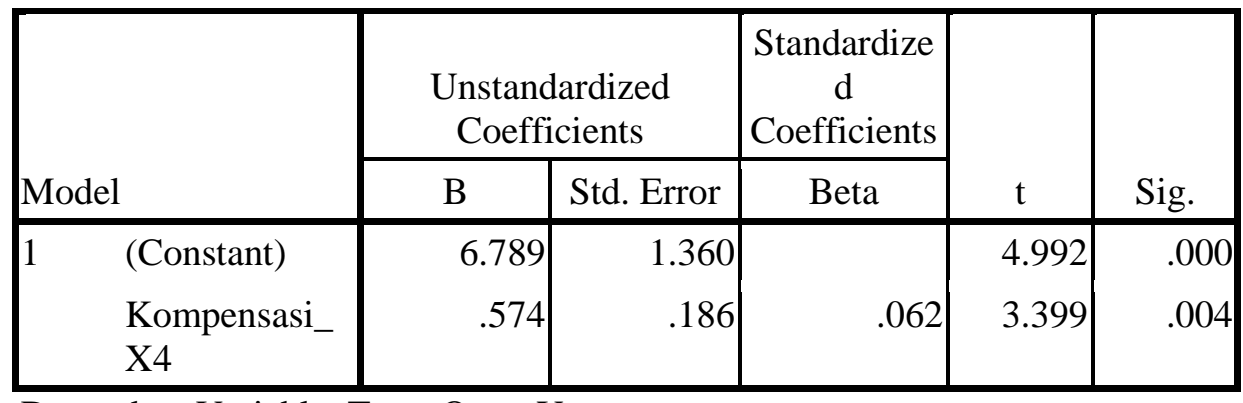

Dependent Variable: Turn_Over_Y

Berdasarkan tabel 4. coefficient di atas, persamaan analisis regresi linier sederhana yang diperoleh adalah $Y=6,789+0,574$. Sedangkan untuk pengujian hipotesis yang ditunjukkan oleh nilai t bahwa t hitung yang diperoleh adalah sebesar 3,399 dengan nilai signifikansi sebesar 0,004 lebih kecil dari taraf kesalahan 5\%, hal tersebut menunjukkan bahwa variabel kompensasi memberikan pengaruh positif terhadap kepuasan kerja. Hal ini berarti bahwa hipotesa yang menyatakan kompensasi terhadap kepuasan kerja diterima, 
atau Ho ditolak dan Ha diterima. Pembahasan berkaitan dengan pengaruh kompensasi terhadap kepuasan kerja dapat dijelaskan bahwa dalam variable kompensasi yang layak yang merupakan faktor Quality of Work Life dalam organisasi dinilai faktor yang paling signifikan, dimana presepsi mengenai keuntungan yang kompetitif di lihat dari sudut sistem tunjangan, intensif yang di terima, bonus dan pengurusan birokrasi pengurusan klaim kompensasi, dinilai sebagai pemicu kepuasan kerja karyawan dalam hal kompensasi yang layak.
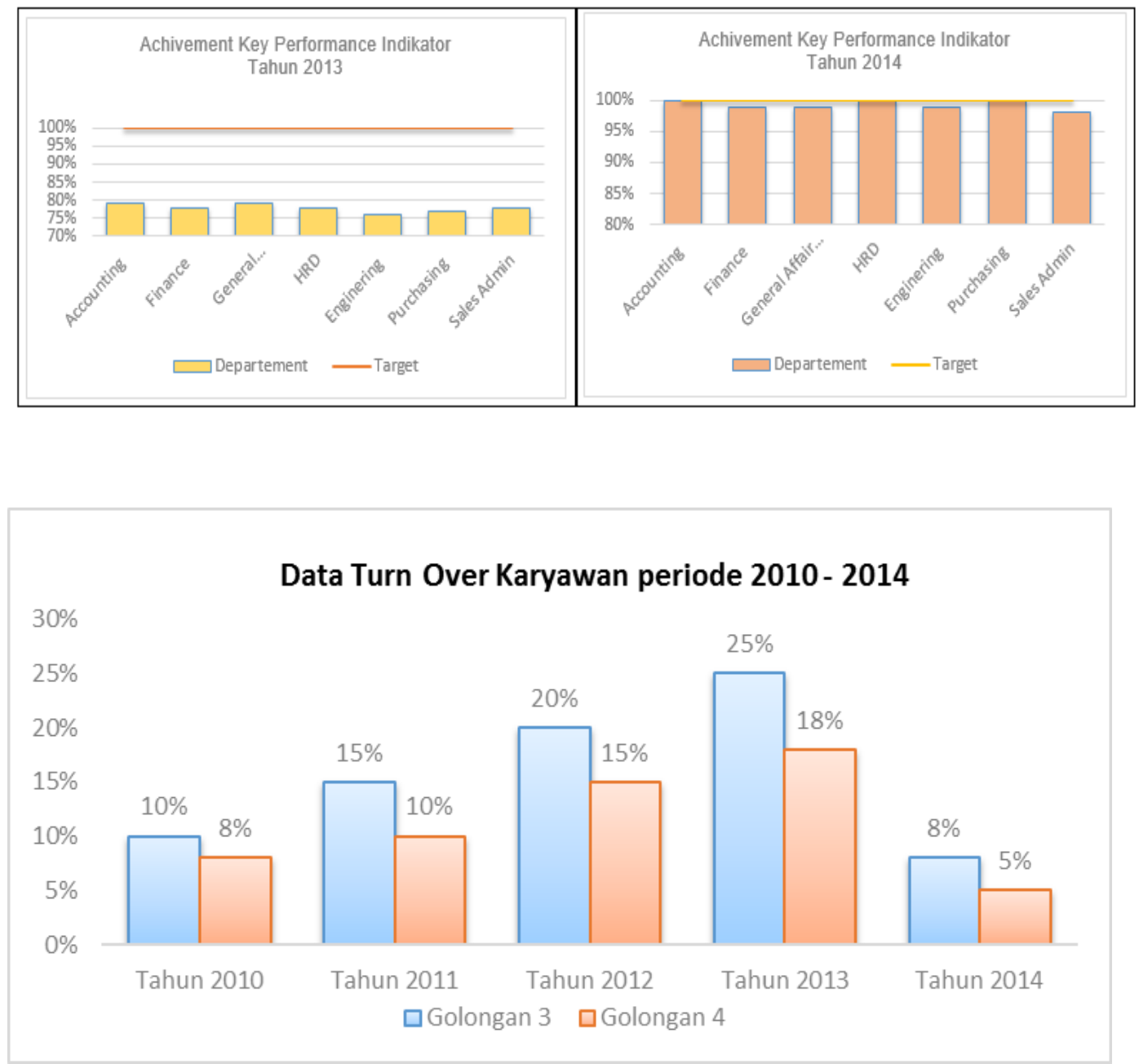

Gambar 1. Analisis Kondisi sebelum dan sesudah

Berdasarkan Achivement Key Performance Indicator tahun 2013 dan 2014, bahwa pada tahun 2014 terdapat kenaikan score KPI jika dibandingkan dengan tahun 2013. Adapun kenaikan score tersebut jika dirata - ratakan untuk departement yang berada di area Head Office sebesar 27\%. Hal ini mengindikasikan bahwa setelah di implementasikanya penelitian, kinerja karyawan meningkat jika di bandingkan dengan tahun 2013. Tentunya hal ini menjadi dampak positif bagi perusahaan dan diharapkan dengan adanya penelitian ini, program - program yang berdasarkan faktor faktor QWL yang ada, tentunya harus memiiki kemampuan untuk beradaptasi dengan perubahan, agar dapat sesuai dengan kondisi \& lingkungan. Selain itu perusahaan juga harus mampu merespon perubahan yang terjadi dan terus berkembang dengan cara continuous improvement, sehingga kinerja para karyawan terus meningkat dan 
tercapainya tujuan perusahaan. Berdasarkan Data turn over karyawan untuk periode 20102014, dapat dilihat bahwa pada tahun 2014 (setelah di implementasikanya penelitian) terdapat penurunan angka turn over untuk karyawn golongan 3 dan 4 yakni sebesar $68 \%$ (karyawan golongan 3) dan $72 \%$

;(untuk karyawan golongan 4). Hal ini mengindikasikan bahwa setelah di implementasikanya penelitian kepuasan kerja karyawan meningkat jika

\section{SIMPULAN DAN SARAN}

1. Dari hasil perhitungan data untuk variabel Partisipasi karyawan $\left(\mathrm{X}_{1}\right)$ diperoleh t hitung sebesar 6,263 dengan nilai signifikansi sebesar 0,014 lebih kecil dari taraf 0.05, yang menunjukkan adanya pengaruh signifikan terhadap kepuasan kerja ( Y ), untuk variabel Pengembangan Karier $\left(\mathrm{X}_{2}\right)$ diperoleh t hitung sebesar 5,577 dengan nilai signifikansi sebesar 0,000 lebih kecil dari taraf kesalahan 0.05 , yang menunjukkan adanya pengaruh signifikan terhadap kepuasan kerja ( $\mathrm{Y}$ ), untuk variabel Komunikasi (X3) diperoleh t hitung sebesar 4,590 dengan nilai signifikansi sebesar 0,000 lebih kecil dari taraf kesalahan 0.05 , yang menunjukan adanya pengaruh signifikan terhadap kepuasan kerja ( $\mathrm{Y}$ ), untuk variabel Kompensasi (X4) diperoleh t hitung sebesar 3,399 dengan nilai signifikansi sebesar 0,004 lebih kecil dari taraf kesalahan 0.05 , yang menujukan adanya pengaruh signifikan terhadap kepuasan kerja, sehingga dari ke empat varibel bebas yang memberikan pengaruh terbesar terhadap kepuasan kerja adalah varibel Partisipasi karyawan $\left(\mathrm{X}_{1}\right)$ karena memiliki nilai koefisien regersi terbesar yakni 6,263.

2. Setelah dilakukanya penelitian dan di implementasikanya program berdasarkan Quality of Work Life di PT. Gemala Kempa Daya, terdapat kenaikan kinerja karyawan di Departement area Head office sebagai berikut : Departement HRD terjadi kenaikan score pada KPI sebesar 28\% (Jika dibandingkan Key Performance Indicator 2013), Departement Sales Admin terjadi kenaikan score pada KPI sebesar 26\% (Jika dibandingkan Key Performance Indicator 2013), Departement Finance terjadi kenaikan score pada KPI sebesar 27\% (Jika dibandingkan Key Performance Indicator 2013), Departement Purchasing terjadi dibandingkan dengan tahun 2013, walaupun angka penurunan turn over karyawan belum sesuai dengan yang di targetkan oleh pihak perusahaan ( < 5\%/ Tahun ), namun perusahaan tetap optimis dengan di lakukanya program - program yang berdasarkan faktor - faktor QWL, serta beberapa program usulan dan tentunya program - program tersebut masih terus dikembangkan (continuous improvement) dapat mencapai target tersebut.

kenaikan score pada KPI sebesar 30\% (Jika dibandingkan Key Performance Indicator 2013), Departement Genera Affairl \& CSR terjadi kenaikan score pada KPI sebesar 25\% (Jika dibandingkan Key Performance Indicator 2013), Departement Accounting terjadi kenaikan score pada KPI sebesar 27\% (Jika dibandingkan Key Performance Indicator 2013), Departement Enginering terjadi kenaikan score pada KPI sebesar 30\% (Jika dibandingkan Key Performance Indicator 2013).

3. Berdasarkan perbandingan kondisi sebelum dan sesudah dilakukanya penelitian, tentunya hal ini berpengaruh pada data KPI dan Turn Over, bahwa pada tahun 2014 terdapat kenaikan score KPI jika dibandingkan dengan tahun 2013. Adapun kenaikan score tersebut jika dirata - ratakan untuk departement yang berada di area Head Office sebesar $27 \%$, sementara untuk turn over bahwa pada tahun 2014 (setelah di implementasikanya penelitian) terdapat penurunan angka turn over untuk karyawn golongan 3 dan 4 yakni sebesar 68\% ( untuk karyawan golongan 3) dan $72 \%$ ( untuk karyawan golongan 4).

\section{SARAN}

Melihat dari hasil penelitian yang menunjukan bahwa adanya pengaruh dari 4 faktor QWL terhadap kepuasan kerja karyawan, adapun strategi yang dapat dilakukan oleh perusahaan adalah dengan berusaha untuk meningkatkan kepuasan kerja karyawan terhadap ke 4 variabel Quality of Work Life yang telah di paparkan dalam penelitian ini, yaitu dengan cara melanjutkan secara lebih optimal program kepuasan kerja yang telah ada di perusahaan yang telah 
Meri Prasetyawati, Kusnudin : Pengaruh Quality Of Work Life Terhadap Kepuasan Kerja Karyawan Di PT. Gemala Kempa Daya Jurnal Teknologi. 8 (1) pp 9-15 @ 2016

berjalan dengan baik dan mengaplikasikanya.

\section{DAFTAR PUSTAKA}

Ashar, S.M, 2012, Psikologi Industri \& Organisasi , Jakarta, UI- Press.

As'ad, M, 2003, Psikologi Industri, Yogyakarta, Liberty.

Drs. Husein Umar, S.E.,M.M.,MBA, 2001, Riset Sumber Daya Manusia, Jakarta, PT Gramedia Pustaka Utama.

H. Hadari Nawawi, 1998, Manajemen Sumber Daya Manusia, Yogyakarta, Gaja Mada University Press.
Nilda Tri Putri, 2012, Perancangan Standar Penilaian Kinerja Pemeliharaan Lampu Jalan Berdasarkan Key Performance Indikator, Universitas Andalas Padang, Jurnal Optimasi Sistem Industri,

Ronald E. Walpole, Pengantar Statistik, 1993, Jakarta, PT Gramedia Pustaka Utama. 
